\title{
En multidimensionell modell för analys av bruk och beroende av alkohol och droger
}

SAM LARSSON, THERESE VON BRAUN, JOHN LILJA

Kapitlet syftar till att presentera en multidimensionell modell för analys av bruk, missbruk och beroende av lugnande medel, alkohol och narkotika. Modellen positioneras i förhållande till olika teoribildningar som används för att förstå alkohol- och drogbruki dess olika former som brukl riskbruk/missbruk/beroende.

\section{Inledning}

Syftet med artikeln är att presentera en multidimensionell modell för analys av

\footnotetext{
Sam Larsson är professor i socialt arbete och docent i psykologi. Han är verksam som professor vid Högskolan i Gävle, avdelningen för socialt arbete och psykologi och som docent i socialt arbete vid institutionen för socialt arbete, Stockholms universitet.

Therese von Braun är doktorand i socialt arbete. Hon är verksam vid Högskolan i Gävle, avdelningen för socialt arbete och psykologi och knuten till institutionen för socialt arbete, Stockholms universitet. John Lilja är professor emeritus i socialfarmaci. Han är nu verksam vid Högskolan i Gävle, avdelningen för socialt arbete och psykologi.
}

alkohol och drogbruk. Modellen är enligt vår mening också tillämplig för att beskriva och analysera hur alkohol- och drogbruk kan utvecklas till ett problem i form av missbruk eller beroende.

Artikelns disposition och struktur har följande upplägg för att uppfylla ovanstående syfte:

1. Modellens struktur och innehäl: Först ges en presentation av den multidimensionella modellen och dess teoretiska struktur;

2. Teoretisk positionering: Modellens fördelar och begränsningar diskuteras också via en teoretisk positio- 
nering av modellen i förhållande till några andra liknande tankesätt eller teorier som presenterats i litteraturen;

3. Empiriskt innehåll (illustrativ nivå): Fördelar och begränsningar med modellen illustreras genom att koppla den till illustrativt empiriskt material om personer som utvecklat ett beroende av psykoaktiva medel (psykofarmaka) och som beskrivits i forskningslitteraturen.

Sammantaget uppfyller dessa tre punkter det syfte som angivits ovan.

\section{Modellens struktur: En multidimensionell modell för analys av alkohol och drogberoende}

Lilja, Larsson \& Hamilton (1996) beskriver en multidimensionell modell som fokuserar på att förstå samspelet mellan olika personoch situationsfaktorer vid analysen av alkohol- och drogbruk eller beroende. En detaljerad presentation av den här typen av modell kräver egentligen en noggrann genomgång av begrepp som bruk, riskbruk, missbruk och beroende. Det begränsade utrymme vi här har till förfogande medger dock inte en sådan genomgång. Vi hänvisar därför till andra arbeten som kommenterar dessa begrepp (se exempelvis Andersson \& Spak, 2012; Blomqvist, 2012 a; Fahlke, 2012; Jung, 2010; Sussman \& Ames, 2001; West, 2006).

Modellen, som är inspirerad av Magnusson \& Allens (1983) interaktionspsykologiska perspektiv, har här utvecklats och omarbetats och kan kortfattat beskrivas enligt Figur 1.

\section{Personsidans komponenter}

Det styrande systemet i figuren inkluderar personens kognitiva system inklusive dess emotionella dimensioner. Det styrande systemet har en central betydelse för att förstå exempelvis kognition, besluts- och informationsprocesser. Det styrande systemet innehåller system kopplade till mål, planer, coping-strategier, motivation, självbegrepp och identitet, omvärldsuppfattning samt emotionella dimensioner (Magnusson et al., 1983:19-21; Berzonsky, 1988). Personliga minnen av specifika symtom eller sjukdomar och olika behandlingserfarenheter hör hit. Även minnen av att bruka alkohol och droger kan sägas höra till det styrande systemet (Sussman \& Ames, 2001). Individens antaganden, attityder, värderingar och förväntningar exempelvis kopplade till alkohol och drogbruk hör också till det styrande systemet. Motsvarande system $\mathrm{i}$ individernas medvetande finns både hos klienter och behandlare och kan variera mycket (se Lilja et al., 1996). Komponenterna och processreglerna $\mathrm{i}$ individens kognitiva beslutssystem kan operera både medvetet och omedvetet (Eagle, 1987; Safran et al., 1987; Sussman \& Ames, 2001).

Det biologiska systemet är en viktig individfaktor som inkluderar genetiska och biologiska strukturer och processer. Detta system integrerar med exempelvis det styrande systemet och med individens beteende i olika sociala sammanhang (Magnusson et al., 1983:21). 
När en individ brukar en drog kommer det biologiska systemet och dess funktionssätt att påverkas och analyseras via en kognitiv process hos individen (Lilja et al., 1996). Den biologiska dimensionen har uppmärksammats alltmer vid analysen av olika psykosociala problem inklusive alkohol och drogbruk av forskare exempelvis inom socialt arbete (Amodeo \& Lopez, 2011; Parrish, 2010).

Det observerbara beteendet i modellen omfattar både aktioner och reaktioner som kan tillskrivas individen. Individens beteenderepertoar eller förmågor att agera på olika sätt tillhör detta system (Deikman, 1982).

Intra-personella begrepp och perspektiv: Personsidans komponenter $i$ modellen fokuserar främst på en intra-per- sonell dimension. I forskningslitteraturen diskuteras ofta hur intra-personella (personvariabler) och interpersonella faktorer (situationsvariabler) samspelar vid utvecklingen av alkohol och drogbruk (Jung, 2010; Sussman \& Ames, 2001). De intra-personella teorierna betonar intra-personliga faktorer exempelvis personlighet, identitet, självförtroende, social förmåga, kognitiva och emotionella coping-strategier som betydelsefulla för i vilken utsträckning som bruk eller beroende av alkohol och droger utvecklas (Jung, 2010:38). Exempelvis kan ungdomar med bristande skolframgång använda alkohol som ett sätt att kognitivt-emotionellt hantera sina svårigheter i skolan. Ungdomar med bristande framgång i skolan tenderar även att söka sig till kamratgrupper med liknande problem, där hög alkoholanvändning kan vara ett sätt

\section{Figur I.}

En multidimensionell modell för beskrivning och analys av bruk, missbruk och beroende. Modellen innehäller fyra centrala komponenter som interagerar med varandra och vars samspel är av betydelse vid analysen av alkohol- och drogbruk. Modellen är inspirerad av Magnussons et al. (1983) interaktionspsykologiska modell.

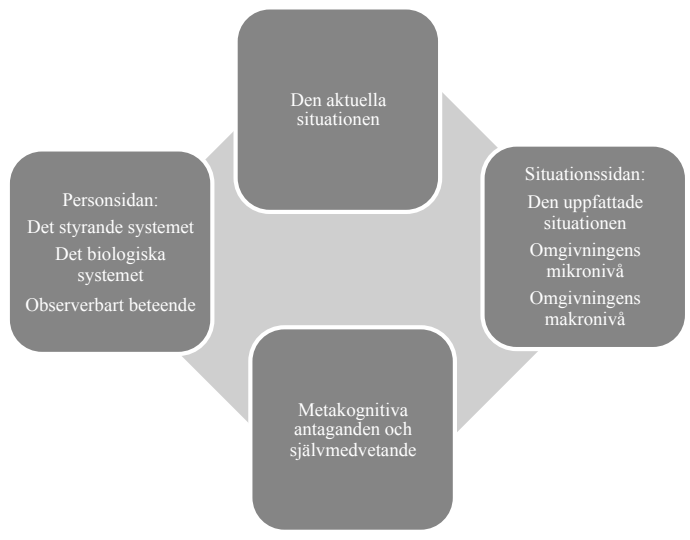

Larsson, von Braun \& Lilja: En multidimensionell model för analys... 
att handskas med känslor av misslyckande i skolan (Jung, 2010:38; Lilja \& Larsson, 2003).

Den intra-personella dimensionen kan i vidare mening således sägas omfatta individens biologi, olika personlighetsfaktorer, kognitiva processer och emotionella upplevelser. Man kan något förenklat säga att dessa faktorer sker "inom" individens psykiska upplevelsevärld. Dessa psykiska faktorer påverkar hur individen samspelar med sin omgivning (Sussman \& Ames, 2001:56). De biologiska processerna kan uppvisa variationer i de neurokemiska systemens funktionssätt hos olika personer som kan förklara individuella skillnader i reaktionen på bruk av alkohol och droger (Cloninger et al., 1993; Olson et al., 1992; Sussman \& Ames, 2001:70). Olika personlighetsdrag ("personality traits") såsom sensationssökande beteende, impulsivitet eller svårigheter att behärska sitt temperament genom att överreagera kan utgöra skäl till att bruka droger (Sussman \& Ames, 2001:71-72).

Kognitiva-emotionella förväntningar kan motivera användning av alkohol och droger. För vuxna har skilda negativa upplevelsetillstånd såsom ilska, sorgsenhet, ångest, depression, skuldkänslor och upplevelser av stress visat sig påverka återfallsfrekvensen vid alkoholproblem (Marlatt \& Gordon 1985; Miller, 1991; Sussman \& Ames, 2001:72). Empiriska data indikerar att brukare och beroende personer kan använda droger som en form av självmedicinering eller självreglering av negativa emotionella tillstånd (se Sussman et al., 2001:72). Motiven till alkohol och droganvändning kan vara många exempelvis att minska negativa känslor eller skapa mer positiva känslor (Jung, 2010:39). Kognitiva förväntningar och positiva minnen av alkoholanvändning kan vara motiverande faktorer till fortsatt bruk (Sussman et al., 2001:73). Stress och spänning kan vara ingångar till beroendeproblem. Att använda alkohol kan vara ett sätt att handskas med stress och det kan tillfälligtvis reducera känslor av ångest och depression (Sayette, 1999; Jung, 2010:39).

Identitet och självbild: Identitetsupplevelsen är en viktig faktor som ingår i personssidans styrande system och som har koppling till exempelvis alkohol- och drogbruk på olika sätt. Ungdomar med hög grad av identitetsosäkerhet har högre alkoholkonsumtion och har oftare prövat droger än de som inte upplever sådan osäkerhet (se Lilja et al., 2003:52). Empiriska undersökningar visar dock att det direkta sambandet mellan självförtroende och alkohol/drogbruk är relativt svagt i statistisk mening (Jessor et al., 1977; Lilja et al., 2003:113). Lågt självförtroende tenderar dock att ha samband med positiva alkoholförväntningar (Nyström, 1993).

Även om man endast finner ett svagt direkt samband mellan självförtroende och alkohol/drogbruk kan självförtroende vara en viktig variabel som kan underlätta eller försvåra ny inlärning. Sambanden blir komplicerade eftersom undersökningar antyder att självförtroendet hos ungdomar bland annat påverkas av skol- och kamratanknytningen (Kumpfert et al., 1990-91). Ett lågt självförtroende kan påverka valet av kamrater. Det finns en risk att ungdomar med svag skolanknytning väljer kamrater 
som också har svag skolanknytning och ett omfattande alkohol- och drogbruk (se Lilja et al., 2003:113, 185).

Resultat från vissa undersökningar tyder på att självförtroendet kan påverka ungdomars förmåga att hantera stress och negativa livshändelser och därmed benägenheten att använda alkohol/droger som coping-strategi (Hoffman et al., 1998, Lilja et al., 2003:111-113). Singer (1993) och hans kolleger har påvisat en korrelation mellan de tillfällen då en individ tar kokain och upplevelser av låg självkänsla. Många som brukar-missbrukar alkohol och droger upplever en annan identitetsupplevelse jämfört med när de inte använder alkohol och droger. Identitetsupplevelsen med alkohol och olika droger kan hos vissa individer innebära en större självkänsla eller identitetssäkerhet, som kan göra att individen kan relatera till andra med en större grad av självförtroende (Denzin, 1987; Heyman, 2009; Larsson 1992, Larsson et al., 2001 a, b; Lilja \& Larsson 2003; South, 1999).

\section{Metakognition och självmedvetandeprocesser}

En individ har, förutom förmågan att via det styrande systemet kognitivt och emotionellt bearbeta sin situation, också en mer eller mindre välutvecklad förmåga att "tänka på sitt tänkande" eller vad som brukar benämnas metakognition (Antaki \& Lewis, 1986). Det handlar om en kapacitet till mental spegling av de egna kognitiva och emotionella processerna Den här typen av självmedvetandeprocesser eller att "vara medveten om att vara medveten" har visat sig ha stor betydelse vid alkohol och drogberoende. Självmedvetandeprocesser eller i vilken grad individen är medveten om sitt eget beteende och sina egna känslor har visat sig kunna minska ett negativt inflytande med koppling till alkoholproblematik i familjen under uppväxtåren (Rogosch et al., 1990). Självmedvetande har visat sig vara en modererande faktor för individer med en alkoholproblematik i sin familjehistoria. Individer med alkoholproblematik i sin familjehistoria och med bristande förmåga till självmedvetande löper större risk att utveckla alkohol- och drogproblem vid stressituationer senare i livet än individer med liknande bakgrund som har större förmåga till självmedvetande (Jung, 2010:48) Figur 1 identifierar just individens förmåga att via metakognition och självmedvetandeprocesser kritiskt värdera sina kognitiva och emotionella reaktioner, tillhörande personsidan, men också förmågan att kunna reflektera kritiskt över den aktuella situationen, hur den upplevs/tolkas, vilket hör till situationssidan i modellen.

\section{Situationskomponenter}

Den aktuella situationen kan på ett sätt sägas tillhöra en egen dimension i modellen men den tillhör också situationssidan och syftar på den del av omgivningen som är tillgänglig för perceptuell varseblivning vid ett specifikt tillfälle (Magnusson et al., 1983). Den tolkade eller uppfattade situationen däremot är individens tolkning av den aktuella situationen eller vilken personlig mening som den har för individen. Omgivningens mikronivå syftar på en del 
av den fysiska och sociala omgivningen som en individ är i kontakt med eller samspelar med i ett visst givet ögonblick i det dagliga livet. Omgivningens makronivå omfattar den del av den totala omgivningen som på olika sätt påverkar mikrosituationen. När det gäller den sociala situationen syftar denna del av omgivningen på den fysiska, sociala, kulturella, ekonomiska och politiska struktur i samhället där individer växer upp inklusive samhällets lagar, språk och bostäder (Magnusson et al., 1983:11).

Interpersonella begrepp, teorier och perspektiv: Situationssidans komponenter $i$ modellen fokuserar främst på de interpersonella dimensionerna och syftar på faktorer i omgivningen, kulturella och sociala variabler. Det handlar om faktorer som befinner sig "utanför" individen. De interpersonella faktorerna innefattar även interaktioner med andra i olika situationer, social inlärning av olika handlingar, särskilt från s.k. signifikanta andra såsom föräldrar, nära vänner och andra rollförebilder (Sussman \& Ames, 2001:56). Demografiska variabler såsom kön/genus, ålder, etnicitet osv. brukar också hänföras till den interpersonella dimensionen, särskilt om de betraktas utifrån sociologiska eller gruppteoretiska perspektiv (Jung, 2010; Lilja \& Larsson, 2003; Sussman \& Ames, 2001:57).

Genus: Drogbruk är vanligen mer förekommande bland män än bland kvinnor (se Johnstone, 1994; Sussman \& Ames, 2001:57). Män uppvisar generellt sett oftare alkoholrelaterade problem än gruppen kvinnor. Men de kvinnor som har ett allvarligt missbruk uppvisar minst lika mycket eller mer alkoholrelaterade problem än män med ett allvarligt missbruk (Sussman \& Ames, 2001:58).

Ålder: Åldersfaktorn är av betydelse för analys av alkohol och drogrelaterade problem.

Alkoholbruket är störst mellan 26-34 år och bruket av droger har sin topp mellan 18-25 år (Johnstone, 1994). Ungdomars användning av alkohol och droger kan skilja sig från vuxnas bruk (se Sussman \& Ames 1997). Ungdomar kan uppvisa mindre fysiska symtom relaterade till alkoholbruk och i allmänhet konsumera mindre mängder, alternativt ägna sig mer åt storkonsumtion vid särskilda tillfällen s.k. "binge drinking". Beroendeproblem kopplat till bruk av lugnande medel är vanligare bland äldre. De flesta studier visar att alkoholrelaterade problem minskar med stigande ålder (se Jung, 2010:298; Sussman \& Ames, 2001:59-60).

Omgivningsfaktorer: Olika typer av omgivningsfaktorer bör uppmärksammas vid analys av alkohol- och drogberoende. Omgivningsfaktorer som kan vara associerade med experimenterande med droger kan vara bristande organisation i närmaste grannskapet, ekonomisk nedgång och tillgängligheten till droger (Hawkins et al., 1992; Sussman \& Ames, 2001:61 f.).

\section{Den multidimensionella modellen i dialog med relevanta teorierför analys av person-och situationsdimensionerna}

Det finns flera olika relevanta teoribildningar som kan vara av betydelse vid analys 
av person- respektive situationsdimensionerna och dess interaktion i den presenterade modellen. Några exempel på sådana teorier anges i det följande.

När det gäller missbruk eller beroende av alkohol och droger uppmärksammar den psykoanalytiska eller psykodynamiska teoribildningen betydelsen av omedvetna motiv, som i sin tur kan spegla en påverkan av traumatiska emotionella upplevelser från barndomen. Freud ansåg exempelvis att alkoholism inte bara var ett sätt att nå omedelbar behovstillfredsställelse utan också ett sätt att uppleva en känsla av makt eller kontroll. Psykodynamisk teori kan ge ingående kunskap om hur samspelet mellan personen och hennes nära sociala omgivning (mikrosituationen) eller familjemiliön kan beskrivas och hur det kan ha påverkat individens självbild och kognitiva-emotionella funktionssätt, som i sin tur kan ha koppling till bruk av alkohol och droger i vuxenlivet (se Jung, 2010:40-41; Larsson et al., 2001 a, b; Parrish 2010; Skinhöj et al., 2001).

Inom missbruksforskningen har man betonat betydelsen av kognitivt inspirerade teorier. Kognitiv motivation eller förväntningar har diskuterats för att förstå alkohol och drogberoende. Forskare har framhållit att förväntningar är viktiga komponenter i en minnesprocess som i sin tur påverkar beslut om att bruka alkohol och droger (Goldman et al., 1991; Stacy 1995; Sussman \& Ames, 2001:73). Förväntningarna kan vara lagrade i långtidsminnet och de anger vad det betyder för individen att använda alkohol inklusive dess förmodade effekter (Stacy et al., 1994; Stacy 1995; Sussman \& Ames, 2001:73-74).

Kognitiv teori kan bidra till en nära analys av personsidan, särskilt av de kognitiva föreställningar, uppfattningar och bedömningar som individen har kring bruk av alkohol och droger. Ett kognitivt perspektiv kan bidra till en förståelse av hur de som brukar alkohol- och droger mentalt eller metakognitivt förstår konsekvenserna av både tidigare och nuvarande kognitiva upplevelser och beteenden (Hutchison, 2008; Jung, 2010; Lilja et al., 1996; Parrish, 2010:5).

Inom biologiskt grundade personlighetsteoretiska perspektiv har olika sårbarhetsmodeller presenterats där individuella skillnader i personligheten i form av temperament eller biologisk känslighet anförs som förklarande faktorer för skillnader i hur individen reagerar på bruk av alkohol och droger (Jung, 2010:43). Biologiska perspektiv är av stor betydelse för att analysera hur dessa biologiska eller fysiologiska faktorer inverkar på samspelet mellan personoch situationsfaktorer i den modell som beskrivits (se Jung, 2010; Lilja et al., 1996; Magnusson et al., 1983; Milkman et al., 2010; Sussman \& Ames, 2001).

Social (kognitiv) inlärningsteori kan sägas utgöra en specificering av hur sociala faktorer påverkar individen (Bandura, 1986) till att exempelvis bruka alkohol och droger. Det kan ske via inlärning, imitation av rollförebilder för när, hur och var man kan bruka droger. Exempelvis kan man lära sig att det är tillåtet att dricka alkohol under helgerna. Rollförebilder påverkar också hur den sannolika effekten av alkohol- och drogbruk ska tolkas (Jung, 2010:30; Sachachter, 1978; Sussman \& Ames, 2001:67-68). Social inlärningsteori betonar hur förväntningarna formats kring 
effekterna av alkohol och droger via observationer som individen har gjort av sociala samspel där alkohol och droger förekommer (Jung, 2010:30). Brukare av olika droger behöver "lära sig" hur man ska identifiera "effekterna" av drogen och hur dessa ska tolkas i kognitiv-emotionell mening (Sachachter, 1978; Jung, 2010:30).

Utifrån ett systemteoretiskt perspektiv kan analysen av alkohol och drogbruk fokusera på det komplexa samspelet mellan person- och situationsvariabler både på en mikro- (familjesystem) och makronivå (sociala eller kulturella system). Det är inte bara själva bruket av drogen som behöver analyseras. Det är även nödvändigt att sätta in drogbruket $\mathrm{i}$ ett holistiskt perspektiv där man analyserar drogbrukarens liv och samspel med det omkringliggande samhället. Man kan göra systemteoretiska analyser där individens psykologiska upplevelser av drogbruket analyseras i relation till hur olika sociala system inklusive kulturella faktorer påverkar bruket av alkohol och droger (se Barber, 1995:27-49; Jung, 2010; South, 1999).

\section{Teoretisk positionering av den multidimensionella modellen}

I det följande presenteras några teoribildningar och synsätt som vi menar anför liknande argument som den multidimensionella modell vi har presenterat. Det finns dock också viktiga skillnader som vi avser att kort peka ut. Det finns många olika multifaktoriella modeller. De som vi presenterar här har en aktualitet i nuläget (West, 2006) och/eller har presenterats av forskare inom socialt arbete (Barber, 1995; Parrish, 2010).

De valda modellerna kan dock inte göra anspråk på att utgöra ett representativt urval inom området. De tjänar som en viktig relief utifrån vilken vår modell kan tydliggöras.

\section{Relationen mellan biologiska,psykologiska och sociala faktorer}

I den presenterade multidimensionella modellen blir det möjligt att beakta både farmakologiska effekter av alkohol och droger såväl som betydelsen av psykologiska och sociala faktorer. Psykologiska variabler syftar som nämnts i modellen exempelvis på personlighetsfaktorer, temperament och subjektiva upplevelser av förändringar i medvetandet hos den som brukar alkohol och droger. Psykologiska och sociala faktorer behöver enligt modellens synsätt uppmärksammas för att förstå vad som gör att individen börjar bruka droger (se Lilja \& Larsson, 2003). Men efter det att individen börjat bruka droger behöver uppmärksamheten också riktas mot farmakologiska och neurofysiologiska processer för att förstå fortsatt bruk av alkohol och droger, särskilt när det utvecklas till missbruk eller beroende (se Jung, 2010:30).

Den multidimensionella modellen fokuserar på multifaktoriella bio-psykosociala processer och på hur biologiska, psykologiska och sociala processer påverkar varandra ömsesidigt för att exempelvis kunna förstå beroendeutveckling av psykoaktiva substanser i form av lugnande medel, 
alkohol och narkotiska preparat (se Barber, 1995; Cameron, 1995; Goldberg, 2010; Jung, 2010; Sussman \& Ames, 2001, se Figur 2).

Inom socialt arbete har traditionellt uppmärksammats mer holistiska eller ekologiska perspektiv där missbruk/beroende analyserats genom att beakta samspelet mellan individ- och omgivningsfaktorer. Individfaktorer som har beaktats är exempelvis kognitiva och emotionella dimensioner, men man har också uppmärksammat sociala systemfaktorer, familjeprocesser och olika kulturella faktorer vid analysen av beroendeutveckling (Amodeo \& Lopez, 2011; Barber, 1995; Cameron, 1995; Goldberg, 1999, 2010; South, 1999).

\section{Robert West syntetiserande teori}

Blomqvist (2012, a, b) har beskrivit multi- faktoriella modeller, både som en "statistisk modell" och i form av en "aktörsmodell". Blomqvist nämner integrerande eller syntetiserade teoribildningar med särskild hänvisning Robert West syntetiserande teori om beroende, som i grunden är en syntetiserande teori om motivation. Robert West (2006) syntetiserande teori är mycket komplex och beaktar många psykologiska och sociala dimensioner. Blomqvist (2012 a) beskriver West teori som ett "försök att utveckla en heltäckande och övergripandesyntetiserande - teori, med syfte att kunna ge en realistisk bild av addiktioner (eng. addiction) så som de utvecklas och manifesterar sig i verkligheten"(a.a. s 158).

Ett led i West (2006:29 ff.) argumentation är att uppfatta "addiktioner" som uttryck för ett val "addiction as choice". West visar också att det inte är tillräckligt att analysera addiktioner som endast ett resultat av ett val. Ett val, menar West, kan uppstå endast om individen på en

\section{Figur 2.}

En bio-psykosocial modell för beskrivning av den ömsesidiga interaktionen mellan biologiska, psykologiska och sociala processer.

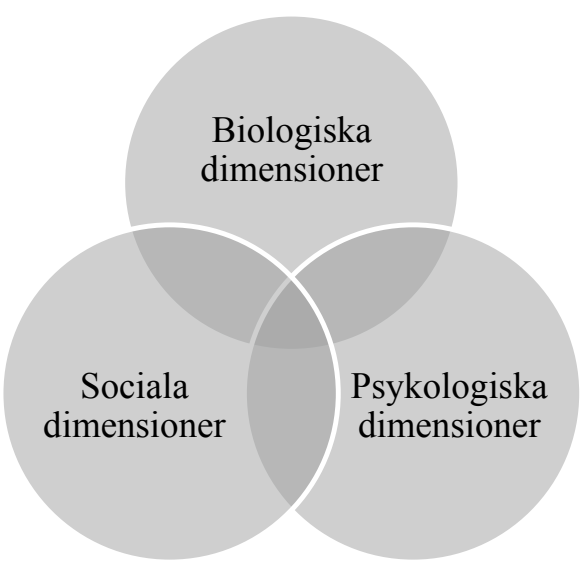

Larsson, von Braun \& Lilja: En multidimensionell model för analys... 
medveten nivå kan välja mellan alternativ (a.a. s 121). West visar dock hur addiktioner också uppkommer som ett resultat av instrumentell inlärning, via klassiska och operanta inlärningsmekanismer, som opererar omedvetet eller bortom det medvetna jagets kontroll och som registreras i minnessystemet och påverkar individen (West, 2006:91 ff., 101). Även sociala inlärningsteoretiska dimensioner har betydelse i West modell, där individen lär sig ett drogbeteende via observation och kommunikation med andra, som använder alkohol och droger (West, 2006:106-107).

Särskilt intressant blir West när han beskriver hur viktigt det är att beakta medvetande- och identitetsdimensionerna för att förstå addiktioner. West beskriver addiktioner som ett resultat av ett instabilt medvetande ("the unstable mind", a.a. 8, 167 ff.) med motivationssystem som opererar på ett obalanserat och destruktivt sätt där individen är fångad av att vilja uppleva ett förändrat medvetande via alkohol och droger. En aspekt av ett sådant behov i medvetandet kan vara att individen brukar alkohol och droger som ett sätt att handskas med negativa livsupplevelser (a.a. 36). Vidare, en negativ jag- eller identitetsupplevelse kan medföra ett depressivt medvetandetillstånd och bruk av alkohol och droger kan då, menar West, utgöra ett sätt för individen att skapa ett mer positivt självförtroende och att förändra jagupplevelsen i mer positiv riktning (West, 2006:72, 162-64). West visar på ett intressant sätt hur olika medvetandeprocesser, psykologiska, kognitiva, emotionella, beteendemässiga inlärningssekvenser inklusive biologiska processer samspelar med sociala dimensioner och sociala inlärningsprocesser för att kunna förstå beroendeproblem.

\section{Analytisk kommentartill Wests teori}

West teoribildning ligger i tiden och andra forskare har presenterat komplexa modellbyggen där man, på liknande sätt som West, betonar individens val vid utvecklingen av beroende. Heyman (2009) diskuterar också beroende, som ett resultat av val och motiverande personlighetsmässiga faktorer ("addiction - a disorder of choice"). Heyman visar med stöd av narrativa berättelsedata hur individer kan beskriva både vägar in i sitt beroende av alkohol och droger och vad som gjort dem motiverade att välja att sluta använda dessa medvetandeförändrande substanser. Heyman visar också hur dessa narrativa data har stöd i omfattande kvantitativa studier eller surveydata från nationella undersökningar som visar att individer som kunnat karaktäriseras som beroende (kopplat till DSM definitioner på beroende) kunnat ("välja" att) sluta bruka dessa substanser (se Heyman, 2009:44-64).

Både vår presenterade multidimensionella modell och Wests modell betonar det komplexa samspelet mellan olika personoch situationsvariabler och båda modellerna betonar betydelsen av kognitions-, inlärnings-, motivations- och identitetsfaktorer (se West, 2006: kapitel 3-5, och s.161-64). Robert West försöker integrera en rad tidigare teoretiska ansatser i sin syntetiserande modell. Wests teori representerar å ena sidan ett viktigt bidrag när det 
gäller att förstå komplexiteten i alkohol och drogberoende med beaktande av olika kognitiva, emotionella, identitetsmässiga och sociala faktorer.

$\AA$ andra sidan är en begränsning med hans modell att den i all sin komplexitet är svår att vetenskapligt pröva i den strikta mening som West själv argumenterar för är önskvärt. Även andra forskare har dragit liknande slutsatser (se Blomqvist, 2012 a:165). I förhållande till vår presenterade modell är Wests modell teoretiskt sett mycket mer komplex men därmed också mer svåröverblickbar genom att den beaktar så pass många faktorer. Vår presenterade multidimensionella modell är influerad av Magnussons et al. (1983) interaktionistiska psykologiska modell, som till viss del har prövats i olika empiriska studier inom psykologiområdet och som därför kan sägas ha ett förhållandevis brett empiriskt stöd även om mycket forskning återstår att göra (se Magnusson \& Allen, 1983; Magnusson \& Endler, 1987).

\section{Barbers holistiska modell}

Barbers (1995) modell uppmärksammar att samspelet mellan person- och situationsfaktorer är av betydelse för att förstå missbruk och han betonar i sin modell att individen och omgivningen behöver sättas in i ett holistiskt systemiskt perspektiv. Barbers analys fokuserar på vilka sociala system som individen ingår i och hur förändringar i ett socialt system kan leda till förändringar i ett annat, som i sin tur kan påverka individens alkohol och drogbruk. Förändringsprocessen vid missbruksbehandling behöver fokusera på flera olika dimensioner (Barber, 1995):

1. Att skapa en kognitiv insikt eller medvetandeförändring hos individen om effekterna av drogbruk eller vad som vidmakthåller beroende.

2. Vad som kan öka möjligheterna för individen att göra ett annat val än att bruka alkohol och droger, vilket ligger i linje med andra forskare som också betonat valmöjligheternas betydelse (se vidare Heyman, 2009; West, 2006).

3. Att via motiverade samtal öka motivationen hos individen att förändra sitt beteende att missbruka droger.

4. Att individen analyserar hur det egna beteendet att bruka droger påverkar närstående och individens sociala situation.

I Barbers modell sker analysen av alkoholoch drogberoende med beaktande av bland annat följande olika interagerande nivåer:

- Symptom- eller situationsnivå, som fokuserar på en situationsanalys;

- Dysfunktionell kognitionsnivå, en nivå som fokuserar på att uppmärksamma individen på de negativa tankemönster eller dysfunktionella kognitiva processer som ofta är involverade och som vidmakthåller beroendet;

- Aktuell interpersonell nivå, interpersonella konflikter med andra individer;

- Allmän systemnivå, familje-/system konflikter där problemet formule- 
ras i termer av kommunikationsproblem och maktobalanser mellan drogbrukaren och signifikanta närstående, som drogbrukaren interagerar med och som påverkar missbruket;

- Intra-personell nivå, med fokus på intra-personella konflikter och inre psykiska spänningar vilket exempelvis psykoanalytisk teori ofta fokuserar på (Barber, 1995:32).

\section{Analytisk kommentar till Barbers modell}

Barbers modell utgår från systemteori i sin analys av interaktionen mellan olika system medan vår modell utgår från interaktionistisk psykologi. Även om vissa likheter finns mellan modellerna är Barbers modell och analys främst inriktad på behandling och specificerar tydliga behandlingsimplikationer medan vår presenterade modell inte ger sådana behandlingsimplikationer utan främst avser att ge en teoretisk analys av drogbruk eller beroende.

\section{Margarete Parrish bio- psykosociala modell}

Margarete Parrish (2010) gör integrerade person- och situationsanalyser av exempelvis beroende av alkohol och droger. Hon nämner att det finns giltiga argument och forskningsevidens både för biologiska, eller genetiska, och psykosociala orsaksförklaringar och att socialarbetare behöver arbeta utifrån en multidimensionell och bio-psykosocial approach. Hon betonar att det kan finnas skäl att beakta dubbla diagnoser där beroendeproblem kan samvariera med andra problem. Den teoretiska analysen behöver, menar Parrish, grundas i flera teoribildningar. Hon nämner bland annat att psykodynamisk teori kan vara av betydelse för att förstå förnekelseprocesser kring problem i samband med alkohol och drogbruk. Ofta förnekar drogberoende de negativa konsekvenserna av sitt beteende och ibland kan också deras familjer vara inblandade $i$ en sådan förnekelseprocess (Parrish, 2010:196).

\section{Analytisk kommentartill Parrish modell}

I likhet med vår modell anger Parrish olika teoretiska analysverktyg med fokus på personens intra-personella värld såsom kognitiv teori och psykodynamisk teori, såväl som ett interpersonellt teoretiskt fokus representerat av social inlärningsteori och systemteori som enligt henne kan vara av betydelsefulla för analys av bruk-missbruk av alkohol och droger (Parrish, 2010: 5-7, 196). Parrish anger dock inte ett utvecklat teoretiskt modellbygge för att förstå eller behandla alkohol- och drogberoende.

\section{Den multidimensionella modellen möter empirin}

I det följande redovisas några empiriska data från en narrativ studie (där en av oss - S. Larsson - var medförfattare) av 50 fall (44 kvinnor och 6 män, Skinhöj, Lars- 
son, Helweg-Jorgensen \& Holme-Hansen, 2001), som fyller syftet att ge empiriska illustrationer till den presenterade multidimensionella modellen.

\section{Fall 1: En manlig sjuksköterska, 44 år, med laingvarigt beroende av psykoaktiva medel}

Detta fall speglar en manlig sjuksköterska som ger viktig information om sina bakomliggande familjeförhållanden och hur dessa kan ha samband med långtidsanvändning av lugnande medel. I denna persons narrativa beskrivning kan man som läsare också få en förståelse för intervjupersonens dåliga självförtroende och identitetsproblem och hur dessa faktorer kan relateras till hans långa beroende av psyko-aktiva droger:

Ibland tror jag att det är därför som allting är så fel med mig. Jag är mycket ensam och vågar inte ta kontakt med andra människor. Jag känner mig ångestfylld, deprimerad och känner mig mycket obekväm. Jag duger inte till någonting, det är på grund av alla piller, somjag använder.

När jag var barn var min far full varje kväll och misshandlade min mor och min lillasyster. Jag försökte att inte bry mig om vad som skedde. Varje sommarlov var jag hos mina farföräldrar som behandlade barn på ett mycket gammaldags sätt. Vi skulle alltid vara rena, tysta och artiga. Min farfar förgrep sig på barn sexuellt. Så jag blev 'tafsad på' av honom varje dag. Om jag protesterade sändes jag hemigen.

I mitt arbete kan man inte visa känslor, så varje dag behöver jag ta tre-fyra piller och ibland mer än så. Jag kombinerar lugnande medel med smärtstillande tabletter som jag använder därför att jag känner mig så tom inombords. Jag har använt lugnande medel sedan jag var 13 år gammal därför att jag hade så många problem under ungdomsåren.

När jag var ung kombinerade jag lugnande medel med alkohol och blev väldigt stökig. Det var därför att jag trodde att jag var som min far. Jag är den i familjen som ser ut som han gjorde. Men senare slutade jag att kombinera lugnande medel med alkohol.

När jag inte är på jobbet behöver jag inte använda lugnande medel överhuvudtaget. Jag vill sluta använda tabletter därför att de fär mig att känna mig så trött och tråkig. Jag får ofta en känsla av att jag inte kan förmå mig själv att göra de enklaste saker. Jag fär inte hälften så mycket gjort som mina vänner klarar, som inte använder tabletter. Det har varit mycket svairt att fatta beslutet, men jag vill sluta använda dem. Kanske vill jag inte sluta därför att tabletterna gör att jag inte kommer ihåg min far - ibland kan jag känna lukten av honom - och hur våldsam han var och jag vill inte tänka på på detta när jag är på jobbet (Skinhöj et al., 2001:1176-1177).

Analytisk kommentar till fall 1: Den narrativa skildringen visar på behovet av en analys av person- såväl som situationskomponenter. Gällande situationssidan kan man konstatera att individen upplevt en mycket traumatisk situation under uppväxten där han blivit sexuellt utnyttjad av sin farfar och upplevt våld i hemmet utfört av 
fadern, vilket kan hänföras till omgivningens mikronivå. Fadern var mycket aggressiv och hade dessutom alkoholrelaterade problem.

Avseende personsidans komponenter uttrycker individen låg självkänsla eller en negativ identitetsuppfattning. Utifrån psykodynamiskt och kognitivt synsätt kan hans, i kognitiv mening, negativa identitetskonstruktion relateras till de traumatiska upplevelserna under uppväxtåren.

I den nu aktuella situationen har han använt tabletter under lång tid särskilt när han ska gå till arbetet. Hans upplevelse tycks vara att långtidsanvändningen av psykofarmaka fyller en viktig funktion genom att tränga bort smärtsamma minnen och känslor som har anknytning till barndomssituationens händelser. Han säger: "tabletterna gör att jag inte kommer ihåg min far". Det föreligger således en komplex personoch situationsinteraktion.

\section{Det illustrerade fallet i ett vidare kontex-} tuellt sammanhang: Det ovan beskrivna fallet var ganska typiskt för det urval som studerades. En traumatisk uppväxtsituation var ett vanligt förekommande tema. En manlig lärare, 43 år gammal, berättade i studien om sitt beroende av lugnande medel och hur det började när han var fem år gammal och en 17 årig pojke försökte att begå ett sexuellt övergrepp mot honom. I samband med den händelsen fick han lugnande medel av en allmänläkare. Under uppväxtåren skrev en allmänläkare fortsättningsvis ut lugnande medel till honom men han fick även dessa medel av sin mor, som använde dessa när hon hade problem i äktenskapet. Mot bakgrund av ett socialt inlärningsteoretiskt perspektiv lärde han sig på så sätt att handskas med svårigheter i livet genom att använda tabletter något som också gick igen i andra sociala situationer. Han berättade exempelvis att: "Jag använde lugnande medel för att... kunna kontrollera mina konflikter med min chef (Skinhöj et al., 2001:1174). Det betyder att hans arbetssituation i nuet präglades av tidigare inlärda mönster att använda psykofarmaka för att lösa svåra problem. Men faktorer med koppling till personsidans variabler var tydligt framträdande även $\mathrm{i}$ hans fall. Han beskrev det så här:

När jag använder tabletter känns det som om jag har en annan identitet jämfört med när jag inte använder piller. När jag använder tabletter känner jag mig mer oberoende. Jag har mer självförtroende och kan göra saker som jag inte vågade göra innan... Och då kan jag tala med andra människor och jag är mer öppen... När jag är utan tabletter, så är jag mycket mer beroende. Jag känner mig hjälplös, kraftlös och oförmögen att påverka händelseförloppet på något positivt sätt... Jag tänker om mina lugnande medel som en del av min kemiska identitet... Men jag vågar inte tala om för någon att jag är beroende av dem (Skinhöj et al., 2001: 1174-1175).

Berättaren uttrycker således en kognitiv identitetskonstruktion med lugnande medel som kännetecknas av en positiv självbild och en mer negativ identitet utan dessa medel. Att individen berättar om sig själv och sin identitetsupplevelse med och utan lugnande medel är också ett uttryck för en metakognitiv evaluering av sin identitets- 
upplevelse. Den här typen av identitetskonstruktioner med respektive utan lugnande medel är ett tema som är ingående belyst i forskningslitteraturen kring beroende av psykofarmaka (se Gabe, 1991; Larsson, 1992; Larsson et al., 2001; Jerome, 1991).

Men också biologiska faktorer har sin betydelse. Många som är beroende av psykofarmaka försöker sluta använda sina lugnande medel eller minska sin dosering men märker att det är svårt därför att de också har utvecklat ett fysiologiskt beroende av dessa medel (se vidare Gabe, 1991; Hallström, 1993; Hofsten 1977; Lilja et al., 2001).

Forskarna har försökt att exempelvis via kvalitativ och narrativt inriktad berättelseforskning inklusive kvantitativa sammanställningar skapa en sammanhängande metaberättelse om utvecklingsstegen vid utvecklingen av beroende av lugnande medel. De olika teman som nämnts kunna ha betydelse för utvecklingen av psykoaktiva droger är följande (Gabe, 1991; Hallström 1993; Hofsten, 1977; Lilja et al., 2001):

(1) En problematisk uppväxt som exempelvis kan innehåller olika former av kränkningar;

(2) Kriser i vuxenlivet;

(3) Inlärningseffekter för individen när denne fått förskrivet psykoaktiva droger för att kunna klara av att hantera svåra situationer och känslor med hjälp av psykoaktiva läkemedel;

(4) Klientens kognitiva förväntningar på tabletterna;

(5) Individen utvecklar en identitet med respektive utan tabletter.
Flera av den beskrivna typen av teman är relevanta i de klientberättelser som skildrats ovan; en problematisk uppväxt, hur man lärt sig handskas med problem och svårigheter via tabletter samt utvecklingen av en identitetsupplevelse med resp. utan de psykoaktiva medlen.

Det är inte bara inom forskarsamhället som man försökt applicera olika typer av multidimensionella modeller för att förstå beroendeutveckling av lugnande medel, alkohol och droger. Även personer som själva har utvecklat ett beroende har diskuterat sin situation i multidimensionella termer. I den omfattande studien av Skinhöj et al. (2001) som skildrats ovan exemplifierades detta med citat från narrativa skildringar från klienter: En klient, med ett långvarigt beroende ställde följande frågor för att försöka förstå både sin situation och sig själv:

- $\quad \ddot{r}$ det min relation till min mamma under min barndom, som fär skulden för allting som man senare upplever i livet?

- Är det en reaktion till mitt äktenskap somblev så dåligt och som sedan blev bättre, utan att man förstod vad som hände? Lurar jag bara mig själv att alling är $\mathrm{OK}$ ?

- $\quad \ddot{r}$ det mina ryggproblem som har plågat mig i över ett år?

- $\quad \ddot{r}$ det min ångest över min operation som inte blev så lyckad?

- Är det min rädsla över att bli arbetslös igen och att då återuppleva känslor av att inte vara tillräckligt bra, något som jag upplevt tidigare?

- Eller är det bara därför att jag inte 
kan koppla av ordentligt och att $i$ sin tur är en konsekvens av mitt mentala tillstånd? (Skinhöj et al., 2001: 1172).

Det finns ett behov av att beakta och kanske integrera både forskar- och klientperspektiv i ett kunskapsbyggande kring bruk och beroende av alkohol och droger. Beaktandet av klientperspektiv i kunskapsutvecklingen har diskuterats på olika sätt i forskningslitteraturen (se Larsson, 1992; Shaw \& Lishman, 1999).

\section{Sammanfattande kommentar}

Den multidimensionella modellen som presenterats kan, menar vi, vara relevant för att analysera bruk och beroende av psykofarmaka, alkohol och narkotika. En analys av personkomponenterna kan öka förståelsen för hur individen kognitivt-emotionellt uppfattar en viss drog och vilken mening som bruket kan ha. Analysen av situationsdimensionerna kan ge kunskap om påverkan kopplat till omgivningsfaktorer. Modellen ger också möjligheter att analysera samspelet mellan specifika personoch situationsfaktorer eller hur individen tolkar bruket av alkohol och droger i en viss aktuell situation och mot bakgrund av olika sociala mikro- och makro-faktorer (Lilja et al., 1996; Lilja \& Larsson, 2003; Larsson et al., 2001 a, b; Parrish, 2010).
Modellen ligger i linje med ledande forskare inom området såsom Jung (2010), som menar att alkohol och drogberoende behöver analyseras multifaktoriellt och med hänsyn till biologiska eller neurobiologiska faktorer, arv och miljöaspekterna, grundläggande psykologiska processer relaterat till kognition, emotion, neuropsykologi, intra-personella såväl som interpersonella faktorer, familjeprocesser, ålder, genus, etnicitet och med beaktande av olikheter för skilda minoritetsgrupper i samhället. Även andra ledande forskare drar liknande slutsatser om behovet av multifaktoriella eller komplexa psykosociala analyser av bruk och beroende av alkohol och droger (se Amodeo \& Lopez, 2011; Cameron, 2004; Heyman, 2009; Sussman \& Ames, 2001; West, 2006).

Den presenterade multidimensionella modellen kan uppfattas som en tentativ modell som möjliggör en systematisk analys av samspelet mellan relevanta person- och situationsvariabler vid bruk/missbruk/ beroende av alkohol och olika typer av droger. Modellens förklaringsvärde behöver dock följas upp i omfattande kvantitativa såväl som kvalitativa studier. Modellen behöver även specificeras ytterligare, framförallt när det gäller beskrivning och analys av hur interaktionen mellan person- och situationsvariabler kan förstås. 


\section{Referenser}

Amodeo, M. \& Lopez, L.M. (2011). Social work interventions with alcohol and other drug problems. In J. Brandell (red.), Theory and practice in clinical social work (s. 525-560) (2nd ed.). London: Sage.

Andersson, A. \& Spak, F. (2012). Riskbruk, missbruk och beroende av alkohol - definitioner och begrepp. (s. 66-74). I C. Fahlke (red.), Handbok i missbrukspsykologi - teori och tilllämpning. Malmö: Liber.

Antaki, C. \& Lewis, A. (1986). Mental mirroring. London: Sage.

Bandura, A. (1986). Social foundation of thought and action: A social cognitive theory. Englewood Cliffs, NJ: Prentice Hall.

Barber, J. G. (1995). Social work with addictions. London: Macmillan.

Berzonsky, M.D. (1988). Self-theorists, identity status and social cognition. In D.K. Lapsley et al., (eds.), Self, ego, and identity. (s. 243-263). Berlin: Springer.

Blomqvist, J. (2012 a). Perspektiv på missbruk och beroende: Från Magnus Huss till Robert West. IC. Fahlke(red.), Handbok i missbrukspsykologi-teori och tillämpning. (s 151-169). Stockholm: Liber.

Blomqvist, J. (2012 b). Sjukdom, dålig vana, livsstil eller social konstruktion? Om olika uppfattningar om missbruk och beroende och deras konsekvenser. I J. Storbjörk (red.), Samhället, alkoholen och drogerna. (s. 14-43). Stockholm: Stockholms Universitets förlag.

Cameron, D. (1995). Liberating solutions to alcohol problems. London: Aronson.

Cloninger, C. R. et al. (1993). A psychobiological model of temperament and character. Archives of General Psychiatry, 50: 975-90.

Deikman, A. (1982). The observing self. London: Beacon Press.

Denzin, N. (1987). The alcoholic self. London: Sage Eagle, M.N. (1987). The psychoanalytical and the cognitive unconscious. In R. Stern (red.), Theories of the unconscious and theories of the self (155-189). New Jersey: Hilldahle.
Fahlke, C. (2012). (red.). Handbok i missbrukspsykologi. Stockholm: Liber.

Gabe, J. (1991). (ed.). Understanding tranquilliser use - The role of the social sciences. London: Tavistock/Routledge.

Goldberg, T. (1999). Demystifying drugs. A psychosocial perspective. London: Macmillan.

Goldberg, T. (2010). Hur blir man narkoman? Och hur hindrar vi det? Solna: Academic Publishing of Sweden.

Goldman, M. S. et al. (1991). Alcoholism and memory. Psychological Bulletin, 110, 137-146.

Hallström, C. (1993). (ed.), Benzodiazepine dependence. Oxford: Oxford University Press.

Hawkins, J. D. et al. (1992). Risk and protective factors for alcohol and other drug problems in adolescence and early childhood. Psychological Bulleting, 112, 65-105.

Heyman, GM. (2009). Addiction - A Disorder of Choice. Harward: Harward Univ. Press.

Hoffman, J.P. et al. (1998). Stressful life events and adolescent substance use and depression. Sub stance Use \& Misuse, 33: 2219-2262.

Hofsten, AM. (1977). Leva med piller. Stockholm: RFHL:s skriftserie nummer 6 .

Hutchison, E. (2008). Dimensions of human behav ior-Person and environment. London: Sage. Jerome, J. (1991). The lost years. London: Virgin. Jessor, R. \& Jessor, S. (1977). Problem behaviour and psychosocial development. New York: Academic Press.

Johnstone, B.M. (1994). Sociodemograhpic, environmental, and cultural influences on adolescent drinking behavior, in National Institute of Alcohol Abuse and Alcoholism (NIAAA). The development of alcohol problems. Research Monographs, no. 26, Rockville, MD: US. DHHS

Jung, J. (2010). Alcohol, other drugs and behavior. London: Sage.

Kumpfert, K.L. et al. (1990-91). The social ecology model of adolescent substance abuse. International Journal of the Addictions, 25:435-463.

Larsson, von Braun \& Lilja: En multidimensionell model för analys.. 
Larsson, S. (1992). Identitet och beroende. Stockholm: Sober.

Larsson, S., Lilja, J. \& Hamilton, D. (2001 a). Identity, cognitive structure and long-term tranquilliser use: A Multidimensional approach. Substance Use \& Misuse, vol. 36, 9-10:11391164.

Larsson, S., Lilja, J., Borg, S., Buscema, M. \& Hamilton, D. (2001 b). Toward an integrative approach in the analysis of dependency problems. Substance Use \& Misuse, vol. 36, 9-10:1323-1356.

Lilja, J. Larsson, S. \& Hamilton, D. (1996). Drug communication. Kuopio: Kuopio University Press.

Lilja, J. \& Larsson, S. (2003). Ungdomsliv, identitet, alkohol och droger. Stockholm: Statens Folkhälsoinstitut.

Lilja, J., Larsson, S. \& Montagne, M. (Eds.) (2001). Special issue on dependence on psychotropics A multidimensional perspective. Substance use and Misuse, vol. 36. No. 9-10.

Magnusson, D. \& Allen, V.L. (1983). An interactional perspective for human development. In D. Magnusson \& V.L. Allen (eds.), Human development - an interactional perspective (s. 3-33). New York: Academic Press.

Magnusson, D. \& Endler, N. S. (1987). Personality at the crossroads: current issues in interactional psychology. New Jersey: Lawrence Erlbaum.

Marlatt, G. A. \& Gordon, J. R. (1985). (eds.), Relapse prevention: Maintenance strategies in the treatment of addictive behaviors. New York: Guildford.

Milkman, H. B. \& Sunderwirth, S.G. (2010). Craving for ecstacy and natural highs. London: Sage.

Miller, L. (1991). Predicting relapse and recovery in alcoholism and addiction. Journal of Substance Abuse Treatment, 8: 277-91.

Nyström, M. (1993). Alcohol use, drinking patterns and indicators of heavy drinking in Finnish university students. Helsinki: University of Helsinki.

Olson, G. A. et al. (1992). Endogenous opiates. Peptides, 13:1247-87.

Parrish, M. (2010). Social work perspectives on human behavior. Maidenhead: Open University Press.

Rogosch, F. et al. (1990). Personality variables as mediators and moderators of family history for alcoholism. Journal of Studies on Alcohol, 51:310-318.

Sachachter, S. (1978). The interaction of cognitive and physiological determinants of emotional state. In L. Berkowitz, (ed.), Cognitive theories in Social Psychology (s. 401-454). New York: Academic Press.

Safran, J.D. \& Greenberg, L.S. (1987). Affect and the unconscious: A cognitive perspective. In R. Stern, (ed.), Theories of the unconscious and theories of the self(s. 191-212). New Jersey: Hilldale

Sayette, M. A. (1999). Does drinking reduce stress? Alcohol Research and Health, 23 (4), 250-55.

Shaw, I. \& Lishman, J. (1999). Evaluation and social work practice. London: Sage.

Singer, J. L. (1993). Experimental studies of ongoing conscious experience. I G. R. Bock et al (red.), Experimental and theoretical studies of consciousness. CIBA symposium 174, Chichester: Wiley.

Skinhöj, K. T., Larsson, S., Helweg-Joergensen, S. \& Holme Hansen, E. (2001). Experiences of longterm tranquilliser use: A psychodynamic perspective. Substance Use \& Misuse, 36 (9-10): 1165-1186.

South, N. (1999). Drugs. London: Sage.

Stacy, A.W. (1995). Memory association and ambigous cues in models of alcohol and marijuana use. Experimental and Clinical Psychopharmacology, 3(2): 183-94.

Stacy, A.W. et al. (1994). Memory accessibility and association of alcohol use and its positive outcomes, Experimental and Clinical Psychopharmacology, 2: 269-82.

Sussman, S. \& Ames, S.L. (2001). The social psychology of drug abuse. Buckingham: The Open University Press.

West, R. (2006). Theory of addiction. Oxford: Blackwell. 


\section{Summary}

\section{A multidimensional model for the analysis of use-misuse of alcohol and drugs}

The chapter presents a multidimensional model where alcohol and drug use-misuse is considered as a multifactorial bio-psychosocial process. The multidimensional model describes the complexity of factors that contribute to alcohol and drug usemisuse and how this makes its study very challenging. The theoretical model considers many dimensions related to different intrapersonal and extra-personal factors affecting alcohol- and drug use-misuse. The intrapersonal influences include processes contributing to personal differences in alcohol and drug use. The focus is especially on neurobiological processes, personality, affective states, including, cognitive motivation or expectancies as behavioral motivators. Extra-personal influences consider demographics, environmental, social and sociocultural factors. 